XINZHONG YAO

\title{
INTRODUCTION: \\ CONCEPTUALIZING VIRTUES IN THE ANALECTS OF CONFUCIUS
}

Few people who love Chinese philosophy do not pay attention to the Lunyu《論語》or the Analects of Confucius. This short book has been at the center of Chinese philosophy, literature, ethics, education, politics, and religion for over two thousand years, and may well have influenced the heart and mind of more people than any other texts of a similar length in the world. The importance of the Analects is not confined to intellectual disciplines; it penetrates all aspects of culture and civilization in China and beyond, and in particular shapes the way of thinking, living, and governing, the last of which can be seen from a once widely circulated saying: "Banbu lunyu zhi tianxia 半部《論語》治天下” (Bringing the order to the world by mastering only half of the Analects) attributed to Zhao Pu 赵普 (922-992), an influential Prime Minister of the Song Dynasty (960-1279) in its early years. ${ }^{1}$

With historically magnified value and meaning, the Analects continues to draw itself attention and is indeed under constant scrutiny and study in contemporary scholarship. Due to the diverse themes manifested in the messages of the Analects, academics from different backgrounds or of different minds often look at it from different perspectives. The fact itself of over a hundred versions in its English translations speaks volumes for the diversity of interpretation and understanding. Translators and interpreters tend to highlight certain messages of the text to reveal or to reemphasize a specific meaning or implication for their readers. To assess and evaluate the achievements of the study of the Analects in recent decades, King's College London, in collaboration with Southeast University (Nanjing, China) and the Chinese University of Hong Kong, organized an "International Forum of the Re-reading of the Analects," October 21-24, 2010. The aim of the forum is to examine and investigate the importance, function, and influence of the Analects in a new attempt to analyze its text,

XINZHONG YAO, Professor, Department of Theology and Religious Studies; Director, King's China Institute, King's College London. Specialties: Chinese philosophy, religious studies, comparative ethics.E-mail: xinzhong.yao@kcl.ac.uk

Journal of Chinese Philosophy 39:1 (March 2012) 3-7

(C) 2012 Journal of Chinese Philosophy 
grammar, structure, concepts, and modes of thought. This aim was achieved through applying new methodologies and perspectives to textual studies in a variety of disciplines such as philology, epistemology, ethics, psychology, historiography, religion, and education.

Over thirty scholars from the UK, Europe, China, Hong Kong, and North America attended the forum, presented their papers and engaged in informative, sometime intensive, discussions, with Professor Tim H. Barrett of the School of Oriental and African Studies (University of London) giving a keynote speech on "The Englishlanguage Analects and Teaching Chinese Studies: Some Reflections on Lesser-known Twentieth Century Translations." During the conference, Professor Chung-ying Cheng, the Editor-in-Chief of the Journal of Chinese Philosophy suggested a special issue be published in this journal by selecting a number of philosophical articles on one of the themes extensively discussed throughout the forum. Having reviewed all papers I found that discussion or examination of conceptualization of virtues central to the text was of prominence in contemporary study of the Analects, and it emerges from the forum that to an extent our understanding of the Analects is influenced or even changed by different interpretations of these virtues. Taking into account the huge importance of this theme, we have also selected a couple of articles outside of the conference papers to form this special issue on "Conceptualization of Virtues in the Analects."

To conceptualize virtues in the Analects, we must see that Confucius and his students (or the authors and compilers of this text) engage virtues at two different levels. At the first level, there are $d e$ 德 (virtue) which appears forty times in the Analects, dao 道 (the Way) which appears eighty-nine times, and ren 仁 (humaneness or benevolence) which appears 111 times. The importance of these virtues is not merely in the quantity of their appearances in the text; they are the fundamental points on which Confucian teachings are converged. As far as their meaning is concerned, they are intended to be "universal," in the sense that they are applicable to all situations and to all people. Unlike in the Daode Jing 《道德經》 where de, dao, and ren are metaphysically unchangeable but can be conceptually fragmented ${ }^{2}$ and are practically graded into different ranks, ${ }^{3}$ virtue, the Way and humaneness in the Analects are taken holistically not only in syntactic epistemology but also in hermeneutic ethics. They cannot be differentiated; nor can they be ranked. They are mutually contained and interchangeable.

Under these above first-level conceptualized virtues we have so-called second-level virtues such as zhong 忠 (loyalty), xiao 孝 (filial piety), gong 恭 (respectfulness), xin 信 (trustfulness), and yong 勇 (courage). Saying that they are of the second level is not because of their lesser importance in the text but because they are treated as 
applications and extensions of the first-level virtues. In the Confucian world, they might be said even more important, as they particularize the universal concepts and enrich or substantialize universal virtue, the Way, and humaneness. If we compare the virtues of the Analects with a house, then the first-level virtues are like pillars and beams, the second-level virtues are like bricks and building blocks; together they constitute the conceptual building of the Analects.

This issue is devoted to the exploration of the structure, interconnection, and meaning of these conceptualized virtues. Professor Chung-ying Cheng provides a structural framework for the theme of the issue in his article entitled "On Internal Ontogenesis of Virtues in the Analects: A Conceptual Analysis." By employing his original and innovative theory of "onto-generative metaphysics" or generative ontology, he attempts to provide an onto-hermeneutic reanalysis of conceptual virtues in the text, arguing that in the process of the appraisal of the internality and activity of the mind an internal activity of the human heart-mind emerges as feedback of the human nature and as a background condition for the emergence of autonomous will as basis of moral value affirmation. His intention is to provide an analysis of how a moral psychology of virtues is founded in the Analects and how such a moral psychology has implications for moral onto-generative metaphysics and onto-generative ethics.

The article by Xinzhong Yao is to engage a relational discussion of dao or the Way through investigating how the concept of the Way is proposed and then applied in the Analects both as a universal norm and as a practical application through an association with other conceptualized virtues such as virtue (de), ability or skill (neng 能), or method (fang 方). Yao argues that the Way, virtue, and practical skills are not three separate themes, but are the three correlative and interinterpreted themes, central to the ethical discourse as constructed in the Analects.

Richard King comes to the conceptualized ren in the Analects from a critical analysis of virtue (arête) in Greek ethics, through which he raises a number of important philosophical questions concerning whether or not ren in the Analects is definable, and if it is, how. King argues that for ethical theorists who are used to a single definition of virtue would most likely feel disappointed as the Analects has offered at least six different characterizations of ren out of which it is impossible to distill one philosophically justifiable definition, as neither functional model nor holistic model would lend any strength to our effort in defining it.

Xinyan Jiang also starts with Greek philosophy, but unlike King who takes Plato and Aristotle as a starting point to examine possibilities of matching Greek concept with Confucian virtue, Jiang applies 
an Aristotlean view of courage to the reinterpretation of yong, which she argues is particularly embodied as a necessary quality in the ideal character of junzi 君子. Jiang argues that although courage of the Analects does not presuppose moral motive, it is a necessary condition for being a truly virtuous person. The courage exhibited by a junzi is therefore necessarily morally good, enabling one to face fearlessly internal as well as external threats to what is right.

Tim Connolly's article is focused on xiao (filial piety), through a conceptual investigation of the origins of philosophical justifications for Aristotelian philia and Confucian xiao. The questions he has asked include: Why does Confucius base the virtuous society on filial relationships, while Aristotle builds it on friendships between equals? What underlying assumptions about bonds between friends and family members do they share or uniquely possess? Does the apparent dissimilarity between xiao and philia mark a deep and unbridgeable gap between their philosophies? He argues that their accounts of human relationships, while different in focus, share many of the same tensions in the attempt to balance hierarchical familial associations with those between friends who are on the same footing.

Last, we come to the paper by Joachim Gantz. Although this article is not exclusively focused on a conceptualized virtue, it has touched upon the question of how to conceptualize sagely wisdom in the Analects. Gantz engages a comparative textual study of the Analects and the Gongyang Zhuan 《公羊傳》, one of the most influential commentaries to the Spring and Autumn Annals during the Han era. The article is divided into three parts. In the first part Gantz argues that the Analects is the only early text in which Confucius is not depicted as the ultimate sage authority who knows an answer to all questions. Instead the Confucius of the Analects leaves questions open and points out limits of possible knowledge. In the second part he shows that we find exactly the same attitudes of Confucius in the Gongyang Zhuan, and in the third part he argues that the specific character of the Lunyu-construction ascribes Confucius professional attitudes which may be possibly found in the realm of historiography and ritual expertise.

To organize an issue with articles from different sources is not an easy job, and I have to confess that it would not have been possible without the constant guidance and editorial advice provided by Professor Chung-ying Cheng, Editor-in-Chief, and Dr. Linyu Gu, Managing Editor, of the Journal of Chinese Philosophy, to whom I owe sincere thanks. I would also like to thank all the participants of the London Forum on the Re-reading of the Analects, and in particular thank the contributors whose papers are included in this special issue, for their scholarship that has made a significant contribution and for 
their untiring effort to make their discussions fitting in with this special issue.

\author{
KING'S COLLEGE LONDON
}

London, United Kingdom

\title{
ENDNOTES
}

1. "He was a devoted student of the Analects of Confucius, and once said to the Emperor T'ai Tsung, 'With one half of this work I helped your father to gain the empire, and now with the other half I am helping your Majesty to keep it." (Herbert A. Giles, $A$ Chinese Biographical Dictionary, republished version [Taipei: Literature House, Ltd., 1962], 75-76).

2. "The man of superior virtue is not (conscious of) his virtue, and in this way he really possesses virtue. The man of inferior virtue never loses (sight of) his virtue, and in this way he loses his virtue." "When the highest type of men hear Tao, they diligently practice it. When the average type of men hear Tao, they half believe it. When the lowest type of men hear Tao, they laugh heartily at it." (Chapters 38 and 41, in A Source Book in Chinese Philosophy, translated and compiled by Wing-tsit Chan [Princeton: Princeton University Press, 1963], 158, 160).

3. "... only when Tao is lost does the doctrine of virtue arises. When virtue is lost, only then does the doctrine of humanity arise. When humanity is lost, only then does the doctrine of righteousness arise. When righteousness is lost, only then does the doctrine of propriety arise." (Ibid., 158). 